\title{
CHARACTERISTICS OF THE PEANUT CHAIN IN EUROPE - IMPLICATIONS FOR PEANUT ALLERGY
}

\author{
Anna M. Prusak ${ }^{1 凶}$, Małgorzata Schlegel-Zawadzka², Annabelle Boulay³, Gene Rowe ${ }^{4}$ \\ ${ }^{1}$ Department of Clinical Nursing, Institute of Nursing and Obstetrics, Jagiellonian University Medical College \\ Kopernika 25, 31-501 Kraków, Poland \\ ${ }^{2}$ Department of Human Nutrition, Institute of Public Health, Jagiellonian University Medical College \\ Grzegórzecka 20, 31-531 Kraków, Poland \\ ${ }^{3}$ Geography, College of Life and Environmental Sciences, University of Exeter \\ Amory Building, Rennes Drive, Exeter EX4 4RJ, United Kingdom \\ ${ }^{4}$ Gene Rowe Evaluation, 12 Wellington Road, Norwich NR2 3HT, United Kingdom
}

\begin{abstract}
Background. Peanuts are one of the main food allergens, occasionally responsible for life-threatening reactions. Thus, many studies have tried to find a connection between peanut allergy prevalence and processes in the peanut chain that may contribute to the peanut allergenicity. To inform this discussion, this paper outlines experiences in peanut cultivation, trade and processing in Europe, focusing on four European countries with different peanut experiences (Poland, Bulgaria, Spain and the UK).

Material and method. Results here are based on documentary analysis and semi-structured, face-to-face interviews with 32 experts involved in various stages of the peanut chain, including peanut farmers, processors, traders, food technologists and manufacturers.

Results. A common peanut chain diagram has been drawn considering shelled and in-shell peanuts. The analysis of each stage of peanut processing has been made in accordance with this peanut chain schema. Thermal and mechanical processes are discussed alongside the resultant end peanut products available for European consumers. The paper also analyses the main trends of peanut trade in Europe. The results suggest that the majority of peanut products in Europe are roasted, implying enhanced exposure of the population to more allergenic peanuts.

Conclusion. The presented schema and related discussion bring together diverse aspects of peanut production, trade and processing. The main factor associated with the increased allergenicity of peanuts appears to be high temperature roasting. Frying and boiling are also thermal processes, but fried and boiled peanuts have been associated with reduce peanut allergenicity. Neither country of origin nor cultivar type appear to be related to differential peanut allergenicity. More research is needed as regards the impact of various additives, such as chocolate (which is also considered an allergen) on the allergenicity of peanut products. The use of peanuts in non-food products also needs more investigation.
\end{abstract}

Key words: peanut allergy, peanut chain, peanut processing, peanut cultivars

\section{INTRODUCTION}

Peanuts, also called groundnuts, are a very popular snack and a frequently used ingredient of many products. They are a very nutritious food, constituting a highly concentrated source of protein and oil,

\strada@cm-uj.krakow.pl

(c) Copyright by Wydawnictwo Uniwersytetu Przyrodniczego w Poznaniu 
and a range of nutritionally important minerals, such as $\mathrm{Na}, \mathrm{K}, \mathrm{Ca}, \mathrm{Mg}, \mathrm{Fe}, \mathrm{Cu}, \mathrm{Zn}, \mathrm{Mn}$ [Khalil and Chughtai 1983]. Thus, institutions such as the American Dietetic Association recommend peanuts as part of many diets, i.e. for vegetarians or for pregnant and breastfeeding women, as well as for children at nutritional risk [Craig and Mangels 2009]. Groundnuts are also advised for diabetics: as legumes, they contain slowly digested carbohydrates and have a high fiber content, which improves glycemic control and reduces incidences of diabetes. On the other hand, peanuts have been classified as "top allergens" or "major food allergens" [Directive... 2003].

In recent years, a slight decrease in peanut consumption has been observed in all European countries, which may be due to intensive campaigns about food allergies. Unlike other allergens, such as milk or fish, peanuts do not constitute an essential part of everyday diet and can be easily eliminated without the risk of malnutrition. Moreover, peanuts account for the most life-threatening or fatal allergic reactions to foods [Bock et al. 2007]. So far, there has been no comprehensive study concerning production, processing, use and consumption of peanuts in European countries. It is not our objective to establish a link between the peanut food chain characteristics and allergy prevalence, as there is no systematic data on peanut allergy prevalence over years. However, evidence shows a systematic increase in the prevalence of various allergies in society, including peanut allergy [Fernández-Rivas and Asero 2014]. Due to low availability of relevant information and knowledge gaps in the existing literature and documents, the present study is based on interviews with experts involved in various stages of the peanut chain, such as peanut farmers (where approapriate), peanut processors, peanut traders, retailers, market specialists, technologists and food manufacturers who use peanuts in their production. The results have allowed to draw a peanut chain diagram, demonstrating critical points in processing technologies and presenting all forms of final peanut products available at the European market.

Interviews with the relevant experts were conducted in four European countries with different peanut experiences, namely Poland, Bulgaria, Spain and the UK. These countries were selected as differing in terms of geographic location (north and south Europe) and their length of presence in European Union (i.e. "old" and "new" members). In the peanut context, their profiles also vary according to the amount and form of peanuts produced, consumed and traded over time. Specifically, Bulgaria and Spain are both peanut producers with long-term tradition in peanut cultivation, although at present only Bulgaria counts as a significant peanut producer in European scale, providing approximately $70 \%$ of total EU peanut production and having over $90 \%$ of total EU peanut cultivation area. The role of Spain as a peanut producer has been systematically decreasing since the mid 90's and now is negligible, not exceeding $1 \%$ of the total EU peanut production. As peanut cultivation requires specific climate conditions, Poland and the UK do not cultivate peanuts and therefore all peanuts consumed in these countries are imported. A vast majority of peanuts in Europe come from imports. The UK is the largest peanut consumer and one of the leading importers of peanuts in Europe, while Poland is characterised by a systematic growth of peanut supply over recent years.

\section{STATISTICS ON PEANUT PRODUCTION AND TRADE}

The objective of this section is to present basic statistics on production and trade of peanuts, which show the origins and quantities of peanuts consumed and processed in the European countries considered in this paper. Statistical data regarding peanut supply in Europe was retrieved from international databases of the Food and Agriculture Organization of the United Nations [FAOSTAT 2014] and of the European Comission [EUROSTAT... 2014]. The FAOSTAT provides free access to downloadable statistics on the quantity of food production, trade, supply, security, prices, agro-environmental indicators, emissions agriculture, and many other factors. The data is available from 1960 and, dependent on the category, reaches 2009-2012. In some cases (i.e. food supply) the most recent statistics were last updated five years ago.

According to FAOSTAT, total world production of groundnuts in 2012 exceeded 41 million tonnes, and was increasing systematically from about 14 million tones in 1961. The largest world peanut producers and exporters are China, India, and the US. In the last decade, China was providing $30-45 \%$ of world groundut 
production annually - and its role is still increasing. Argentina also plays a major role in the world peanut market, particularly as an exporter. Other significant producers and exporters include Vietnam, Nigeria, Indonesia, Sudan, Myanmar and Ghana. Senegal and Brazil used to be considered as both major producers and exporters in the 70's and 80's, while now their role is minor and steadily decreasing. On the other hand, some countries are not significant as peanut producers but play a key role as peanut exporters, e.g. Israel, Nicaragua and two EU countries, namely Germany and the Netherlands. In 2007, the Netherlands shared $7.2 \%$ of the global shelled peanut export. There are four countries in Europe that currently produce peanuts, namely Bulgaria, Greece, Spain and, in a very small scale, Portugal. In the past, peanuts were also produced in Italy. At present, Bulgaria is the largest European producer of peanuts.

The European Union is the main importer of peanuts worldwide. The yearly import of in-shell peanuts fluctuates between $50 \%$ and $75 \%$ of the world imports of this commodity. According to EUROSTAT, the EU countries import peanuts mainly from Argentina (0.3 million tonnes in 2008), China (0.14 million tonnes in 2008) and USA (0.05 million tonnes in 2008). Other major importers include Brazil, India, Egypt and South Africa, but peanut import from these countries has never exceeded 0.05 million tones. Small amounts of peanuts also come from African countries (Democratic Republic of Congo, Gabon, Ghana and Nigeria). The statistics show that peanuts are imported in three forms: in-shell, shelled and peanut oil. The quantity of peanuts imported and produced by the country is reflected in FAOSTAT by the category of "peanut supply". Total quantity of the European peanut supply (including EU members and non-EU countries) has been systematically increasing since 1961, and reached 748 thousand tonnes of in-shell peanuts and 524 thousand tonnes of shelled ones in 2009. The EU countries also consume peanut oil, but at decreasing rate: from nearly 780 thousand tones in 1968 to only 175 thousand tonnes in 2009. The major European importers of peanuts (in 2009) were the UK (over 250 thousand tonnes), Germany (210 thousand tonnes), France (155 thousand tonnes), the Netherlands and Spain. The UK also comes second with respect to peanut supply per capita $(4.2 \mathrm{~kg})$, after Netherlands $(6.2 \mathrm{~kg})$.

\section{FACTORS INFLUENCING PEANUT ALLERGY}

Peanut allergy starts usually early in life and is more persistant than other food allergies, with only $20 \%$ of patients outgrowing their allergy. Peanut allergy affects on average $1-2 \%$ of the world's population, but the prevalence varies between countries, with the highest rates in the US, Canada and the UK (1-3\%) and the lowest in France, Denmark and Israel (0.2$-0.7 \%$ ) [Fernández-Rivas and Asero 2014]. However, the prevalence of peanut allergy is a growing problem worldwide, especially in developed countries [Vickery et al. 2011]. Many studies have attempted to establish a link between peanut allergy prevalence and various aspects of peanut farming and processing. According to Zhou and coworkers [Zhou et al. 2013] there are three methods of reducing allergenicity of peanuts: physical methods (heat and pressure treatment, pulsed ultraviolet light), chemical methods (tanning acids, magnetic beds) and biological methods (conventional breeding, irradiation breeding, genetic engineering, enzymatic treatment, fermentation). A vast majority of studies exploring allergenicity of peanuts have referred to the processing methods, especially thermal treatment, as being important factors in determining the degree of allegenicity. Thermal processes have been described as 'high impact' in terms of their potential to induce peanut allergy [Boulay et al. 2008].

Thermal processing has been found to influence the allergenicity of peanut proteins by changing their primary structure [Mondoulet et al. 2005]. There are essentially three different thermal processes, namely: boiling, frying and roasting, with roasted peanuts found to be the most allergenic, consequent on the higher temperatures of $120-280^{\circ} \mathrm{C}$ associated with that process [Maleki et al. 2000, 2003]. Roasting changes the chemical structure and organoleptic qualities of peanuts, producing a distinct flavour that many consumers associate with peanuts [Kita and Figiel 2007]. However, the temperature of roasting may vary significantly between various products. For example, peanut flour requires roasting (referred to as "gentle parching") at a temperature of $50-90^{\circ} \mathrm{C}$ [Matsunaga 1974]. The processing method strongly influences national cuisine traditions: sensitization and reactivity to peanuts are less prevalent in China than in the US, despite the high rate of peanut consumption in both 
countries, possibly because in China peanuts are commonly fried or boiled, while in the US peanuts are mostly roasted. However, it has been observed that in most European countries, peanut allergy prevalence is rather low, despite the fact that the majority of products present at the market are based on roasted kernels. High consumption of peanut butter in the US may explain high allergy prevalence in American population, which is not the case of Europe and Asia where people consume roasted peanut in other forms, i.e. in salads, although it is unclear why. It also determines peanut cultivars used, for example Runners and Valenzia are usually consumed in roasted forms [Beyer et al. 2001].

\section{MATERIAL AND METHODS}

The paper is based on documentary analysis and interviews with experts. In general, it was difficult to find relevant and consistent publications with respect to the peanut food chain. Interview participants were identified during the literature review and the historical documentary analysis. Semi-structured interviews were conducted with key informants in the UK, Spain, Bulgaria and Poland in order to obtain their expert views on trends in peanut production, trade and processing. Interviews were carried out with representatives from a number of key informant categories, such as farmers, traders, peanut processors and food manufacturers. They were recruited via invitation (letter or phone), personal networks and using a snowball method (once an informant agreed to participate, researchers would ask if she knew others who might be willing to participate in the study). Most interviews were held face-to-face, with a few done over a telephone where scheduling face-to-face meetings proved difficult. Overall, 32 experts involved in various stages of the peanut chain participated in the survey. Information about the number of interviews conducted in these countries and themes addressed is provided in Table 1.

\section{RESULTS}

The results of the interviews were analysed and three aspects of peanut chain were distinguished: (1) selection of peanut cultivar, (2) peanut harvesting, storage and transportation, and (3) peanut processing methods.

\section{Peanut cultivars}

From over 14000 varieties of peanut in the world, four peanut groups have been distinguished, namely Spanish, Runner, Virginia, and Valencia. The UK trader suggested that most peanuts in the European market are of Runner type. China is the main producer

Table 1. Number of interviews and themes addressed

\begin{tabular}{|c|c|c|c|c|c|}
\hline Participant & Bulgaria & Poland & Spain & UK & Themes addressed \\
\hline Peanut farmers & 3 & not applicable & 2 & not applicable & $\begin{array}{l}\text { general farming practice } \\
\text { peanut farming } \\
\text { storage } \\
\text { trade } \\
\text { peanut allergenicity }\end{array}$ \\
\hline $\begin{array}{l}\text { Traders/ } \\
\text { retailers/ } \\
\text { market specialists }\end{array}$ & 3 & 2 & 4 & 5 & $\begin{array}{l}\text { snack market } \\
\text { peanut market } \\
\text { peanut products } \\
\text { consumer profile } \\
\text { cultivars in peanut products } \\
\text { allergy issues }\end{array}$ \\
\hline $\begin{array}{l}\text { Processors/ } \\
\text { technologists/ } \\
\text { manufacturers }\end{array}$ & 2 & 4 & 3 & 4 & $\begin{array}{l}\text { peanut stock and storage methods } \\
\text { processing methods } \\
\text { products obtained } \\
\text { allergy issues }\end{array}$ \\
\hline
\end{tabular}


of Virginia, but it also grows and exports Spanish peanuts. Virginia-type peanuts are also planted in the US, India and Africa. Spanish-type peanuts are cultivated mainly in the US and South Africa. Key informants demanded different type of information about peanut cultivars dependent on the place in the peanut chain. Specifically, certain cultivars are preferred mainly due to agronomic characteristics, oil content and quality features. Agronomic characteristics play a key role in cultivar selection for the farmers. For example, most Bulgarian varieties have been developed by the Sadovo Institute of Plant Genetic Resources as best suited for local climatic and market conditions (i.e. Kalina, Sadovo 2609). These are early-maturing, suitable for mechanised cultivation and harvesting, with large seeds, high yields (approx. $1500 \mathrm{~kg}$ per 50 ares) and fungi-resistant, which make them less susceptible to aflatoxins. The latter feature places Bulgaria as one of a few countries in the world that do not use chemical fungicides during the peanut vegetation period. Information about oil content is also relevant for peanut processors and traders, with the high oleic varieties (e.g. Flavor Runner 458) expected to have 5-10 times longer shelf life compared to low-oleic ones. Oil content also determines the usability of peanuts for oil. For example, Spanish-type varieties contain more fat than others and therefore are usually crushed for oil.

Almost all peanut chain actors refer to quality features defining products for which peanuts are to be processed. Runner peanuts have medium, but uniform kernel size and are used mainly for roasted and salted peanuts and for peanut butter. The UK manufacturers claimed that Runner (specifically from the US and Argentina) are not so tasty, but safe in terms of aflatoxin and having uniform seeds. Aflatoxin was considered critical by all the respondents and it was discussed extensively with respect to peanut cultivars and country of origin. Thus, Runner from the US and Argentina are preferred by the manufacturers who use the same varieties in particular products to maintain their quality. Besides, taste comes secondary since manufacturers add flavours to peanuts. Virginia peanuts have the largest kernels and are often used in premium packs. A Spanish food manufacturer said that consumers prefer Virginia peanuts because of their large size and relatively low price. Virginia peanuts, blanched or fried, are in fact the most popular after pistachio in Spain. Spanish-type peanuts are sweet and small, covered with a reddish-brown skin. They are predominantly used in confectionary, snacks, peanut butter, ethnic food and health food (raw). Valencia-type peanuts have small and very sweet kernels covered in a lightred skin. They are sold in shell, fresh or boiled, which is considered very tasty. Bulgarian variety Kalina have been described by the farmers as very tasty and aromatic and able to be eaten without processing, but they also claimed that it is of irregular quality, expensive and produced only in small amounts. Thus, Bulgarian food producers prefer to use imported peanuts (mostly Chinese Virginia) due to more favourable pricing.

Some of the respondents revealed that they did not ask for a specific cultivar, but rather looked for taste and size of kernels. A UK trader claimed that small peanuts are generally more tasty, while a UK manufacturer admitted that he selects peanuts based on the price and size of kernels, while type of cultivar is not mentioned in his purchasing contract. In Poland, food producers and traders had no information about which peanut cultivars were preferred or used in peanut products.

\section{Peanut harvesting, storage and transportation}

The initial step in peanut processing is harvesting. Harvesting is usually followed by mechanical drying. Peanuts dry naturally in the field (in Bulgaria) or on a threshing floor which allows control of the humidity level (in Spain) before storage. Moisture in groundnuts should be kept below $12 \%$ to prevent aflatoxin moulds [Emission... 1994]. After being harvested, peanuts are stored in farmers' attics or basements (Bulgaria) or in cold-storage rooms during the summer (Spain). Peanuts are susceptible to aflatoxins because they grow in the ground, where the aflatoxin fungus develops. Aflatoxins cannot be eliminated through processing so it is important to detect them prior to processing. From the mid 90s, EU regulations control the level of toxins and pesticide residues in imports. In the UK, aflatoxins are tested both by the importing companies and the Health Authorities. In Bulgaria, following the EU accession, traders stopped importing peanuts from China during the period of May-September, adopting new regulations concerning aflatoxin control. Bulgarian traders also noted that in the past, much of their peanut import 
came from Sudan, but this has now stopped due to high aflatoxin levels. For the same reason, UK informants claimed that growing peanut imports from Africa and India are used mainly for the bird market and not for food, in spite of their fine taste (India) and organic farming (Africa). This has been a major change, since most peanuts imported to Europe were from African countries for the first decades after the second World War. Moreover, the UK run the so-called groundnut program in Gambia and Senegal, which has turned almost the entire economies of these countries to peanut production. This changed after 1970, following EU aoxin regulation, causing many African countries to stop exporting peanuts to Europe. Only a few of these (e.g. South Africa) have the knowledge and investment to be able to produce quality peanuts on a large scale. On the other hand, traders observed a growing demand for organic peanuts (now approx. 500 tons per 100000 tons of peanuts). However, organic peanuts, certified by the European Soil Association, are also very difficult to provide, mainly because of the possibility of peanut infestation, necessitating fumigation before the peanuts get shipped (and organic fumigants are not particularly effective).

Peanuts are shipped to Europe in 20 or 40 foot containers and are stocked for 3 months in the ship. Although temperature and humidity are controlled, imported peanuts undergo numerous health inspections. Spanish respondents pointed out that peanuts cannot be stored with other dried fruits and nuts. Traders buy peanuts in 20 tones containers, raw or blanched. They store peanuts in temperature controlled warehouses $\left(8-10^{\circ} \mathrm{C}\right)$ in order to avoid the growth of mould, infestation or oxidation (to avoid rancidity). Manufacturers declared that peanuts should be stored in closed premises, with temperatures below $18^{\circ} \mathrm{C}$ and the humidity level not exceeding 65\%. Some UK manufacturers test peanuts for aflatoxin on site. They store peanuts in warehouses under various conditions: some peanuts are stored at ambient temperature $\left(20^{\circ} \mathrm{C}\right)$, while others send them in vacuum bags or controlled temperature. Stored peanuts are spread throughout the year in order to keep the product fresh. Peanuts can be fumigated in the country of origin to avoid risk of infestation. Warehouses are also fumigated $\left(\mathrm{CO}_{2}\right.$ chamber) to decrease the risk of cross-infestation. As such, no pesticides are used and using $\mathrm{CO}_{2}$ is cost effective.
Storage condition is important for the shelf life of peanuts. Shelf life depends on the variety of the peanut and is affected by air, heat, or anything else causing oxidation. Although UK manufacturers declared that peanuts stored in a temperature controlled environment can be kept for a couple of years, Spanish traders pointed out that it has changed. Specifically, five years ago, peanuts could be stored for up to one year. Nowadays, peanuts are usually stored for 10 or 15 days at the most in order to avoid problems with aflatoxins. The maximum time of peanut storage now is about one month. In general, all respondents claimed to use special bags that protect peanuts from humidity and periodically check their stock for infestation. Peanuts are often packed in vacuumed bags (especially fried). The UK peanut manufacturers also added that 25-30 years ago people could buy loose peanuts from market stalls or shops but then the problem of cross-contamination resulted in everything being packaged. Interestingly, no respondents were aware of any legislation regarding the storage of peanuts. Moreover, storage conditions seemed to vary according to the country of origin. For instance, in shipments from the US, silica gel is added to the containers to take out the excess moisture so no mould develops. Some traders agreed that in the USA most of the storage is air-controlled.

\section{Peanut processing}

Major post-harvesting steps include processing for in-shell consumption and shelling peanuts for use in other products. Peanuts undergo various processes, and their sequences are determined by the nature of the final product. These processes can be classified according to: (1) character of processing (thermal and mechanical), (2) shelled and in-shell processing, and (3) products received (end and half-product).

Thermal processes consist of boiling, roasting and frying. Boiling consists in boiling raw and freshly harvested peanuts in salty water for many hours. Peanuts for boiling are available only during the harvesting time (May-November). Boiled peanuts have a short shelf life unless refrigerated or frozen. They are popular in America and China, while being almost unknown in Europe. Roasting, and more specifically "dry roasting", is the process of drying peanuts in a hot air of $120-280^{\circ} \mathrm{C}$. Roasted peanuts are immediately cooled to $30-35^{\circ} \mathrm{C}$ in cooling boxes or conveyors to 
stop the roasting process. Roasting is a time-temperature relationship, but the longer the peanuts are roasted, the darker and harder they get and the more difficult for further processing. Frying, also referred to by the respondents as 'oil roasting', consists of heating peanuts in hot oil $\left(120-150^{\circ} \mathrm{C}\right)$. Fried peanuts are cooled by blowing large quantities of air over them. All peanut processors admitted that roasting and frying are cheap and fast processes. However, the costs of frying depend largely on the costs of oil. The UK processor noticed that the type of oil determines quality of peanuts, for example, the use of rapeseed oil gives a long shelf life, good flavour and ensures there is no issue with GM food. In Poland, palm oil is used to fry peanuts due to its low price. An expert admitted that in Poland, virtually the whole food industry is based on palm oil.

The main mechanical (non-thermal) processes consist of shelling, crushing, blanching, chopping and grinding. Shelling begins with removing the foreign material using various screens, blowers and magnets. Then, peanuts are sized by screen graders to divide pods into desired sizes, so that hulls can be crushed without breaking the kernels. Peanut kernels are separated using shaker screens and air separators. Undersized and split kernels are also removed. Next, peanuts are again screened, sized and graded, then bagged for sale to other users in the peanut processing chain. Split peanuts and peanut hearts are usually crushed for oil, and the leftovers (peanut cake) are sold at the feed market.

Crushing for oil, according to the respondents, is no longer done in Europe but in the country of origin. Some peanut farmers in Bulgaria still produce peanut oil, using lower quality kernels (split or undersized) or peanut hearts. A UK trader mentioned that the last time he sold peanuts for crushing was in 2002. Producers do not want to crush peanuts due to aflatoxin contamination in peanut cake - a case of which happened several years ago. Since then, European crushers have gone for other crops, such as soya or rapeseed, while crushing peanuts is not worth it as they would have to clean up their plant because of allergy cross-contamination issues. Peanut oil can be used as an ingredient in a wide variety of products, including food (i.e. Chinese and Vietnamese dishes, milk blends) and non-food (i.e. medicines - e.g. vitamin D and A, cosmetics). It has many advantages as it is tasteless and can be heated to very high temperatures before it smokes $\left(232^{\circ} \mathrm{C}\right)$, which is hotter than most other cooking oils. With such temperatures, food will cook faster and absorb less oil. In addition, peanut oil does not absorb or transfer flavours, so the same oil can be used repeatedly to cook different foods. However, the consumption of peanut oil in most European countries is systematically declining (epp.eurostat.europa.eu) due to high prices (Poland, Bulgaria), allergy issues (UK) and regulations (Spain). Specifically, Polish and Bulgarian processors and manufacturers said that peanut oil is very expensive compared to a cheap and widely available palm or sesame oil. UK traders claimed that peanut oil was in the past used in fish and chips shops, but now this has stopped for fear that peanut proteins in the oil could make it dangerous for people with peanut allergy. In the USA, peanut oil is highly refined but the processing methods are kept confidential. In Spain, traders complained that the government has not yet modified regulations concerning peanut oil in accordance with the EU, a fact that substantially restricted production and trade of peanut oil in the domestic market.

Blanching is the process of removing the reddish skin covering the kernels. Despite applying high temperatures, this process was referred to by peanut processors as a mechanical process. There are several blanching methods, for example dry and water blanching. Dry blanching heats kernels through a warm air to approx. $138^{\circ} \mathrm{C}$ for 25 minutes to break and loosen the skins, then cools them and passes them through large rollers to rub the skins off. Dry blanching additionally removes the kernel heart (by electronic screening), which is not desired in certain products due to its specific flavour (i.e. in peanut butter). Water blanching uses hot water sprayers to loosen the skins, while spin blanching slackens the skins by the steam and removes them by spinning on revolving spindles as the kernels pass on a conveyor. Whether or not groundnuts are blanched to remove the skins depends on the manufacturer. Some manufacturers request them with the skins on, claiming that this produces a unique flavour and makes the product more attractive visually to the consumer because of the dark spots. Sometimes blanching is performed after roasting, which allows a desired amount of skin to be kept on the kernels. 
Chopping and grinding are purely mechanical processes, however, fried peanuts cannot be easily ground as they are too oily. Moreover, peanuts for grinding should not be over-roasted because they get very hard, and could damage the mills.

Processing for in-shell consumption starts with separating foreign material (i.e. soil, stems and leaves) from the peanut pods, which are then washed in wet sand removing stains and discoloration. In-shell peanuts sold in the shops are mostly roasted, although they are often mistakenly called "raw". Yet, actual raw peanuts are becoming a growing health-food market in the UK. For in-shell roasting, peanuts are cooked at medium heat for about 15 minutes. Peanuts may be plain roasted, or seasoned or salt roasted in-shell. Peanuts are washed and seasoned prior to the roasting by the seasonings dissolved in water and forced through the shells by a pressure process.

Figure 1 presents the peanut processing schema developed based on the interviews with peanut processors from four European countries questioned during the survey. It summarizes information about all types of processes that peanuts undergo (thermal and mechanical), and synthesizes it with information on peanut containing products available at the European market.

Thermal processes are presented in diamondshaped windows as the critical points in considering the influence on peanut allergenicity. According to the processors, blanching can be prepared before or after the roasting or frying of peanuts, and on demand of a food manufacturer. Many products use peanuts with skins, which make a specific flavour, for example coloured peanut dragees popular at the European and US market. Asked whether peanuts are mostly fried or roasted in the chain, a Polish processor was not sure, while in Bulgaria, one processor claimed that fried peanuts are not very popular due to perceived high fat content and risk of rancidity. On the contrary, fried peanuts are increasingly popular in Spain. It is very difficult for an average consumer to distinguish between fried or roasted peanuts. Moreover, as roasting

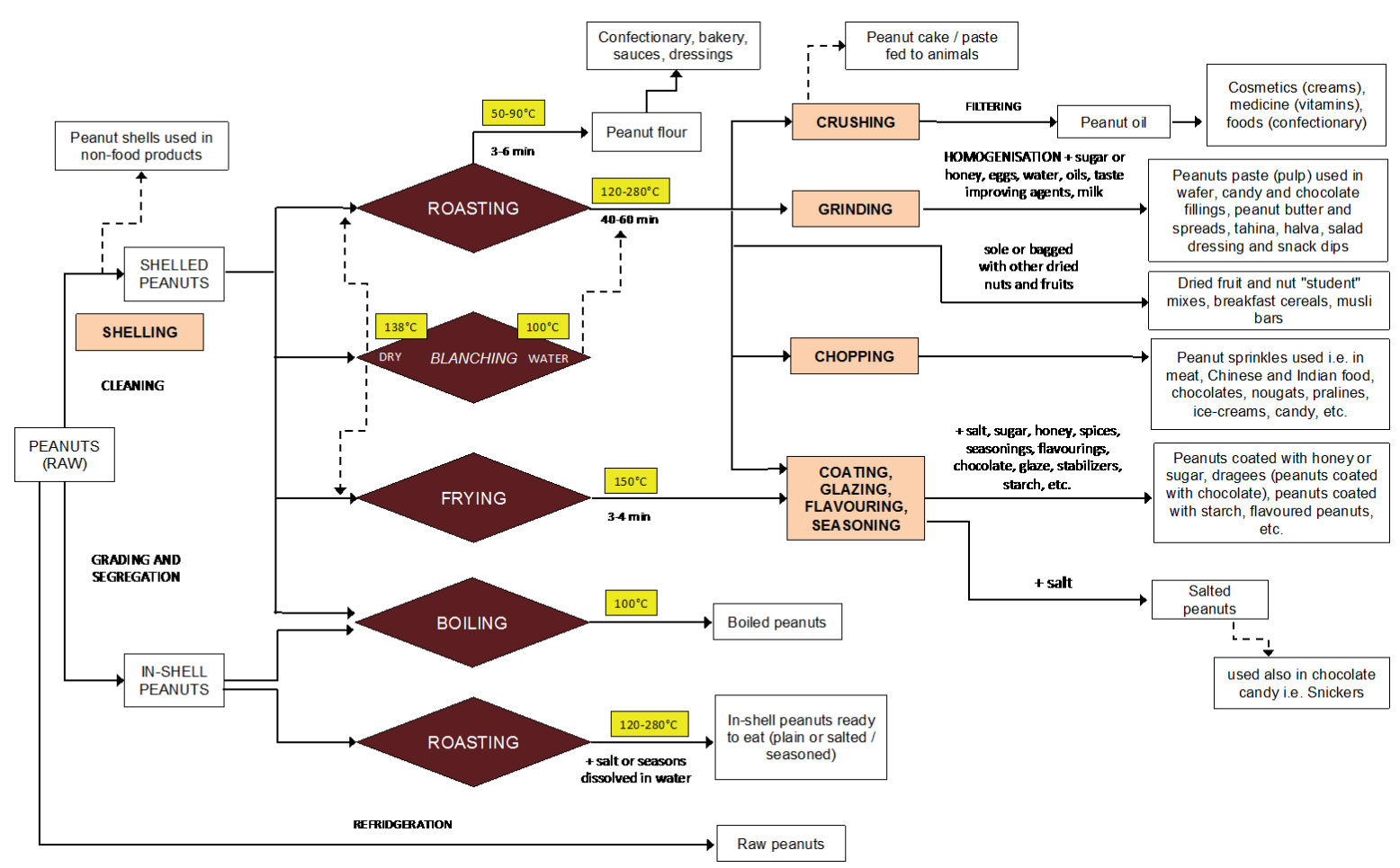

Fig. 1. Peanut processing schema 
is cheaper, some peanut processor in the past used to sell roasted peanuts as fried.

Peanuts can be consumed in a variety of forms and products. The most widely known ones are snacks, salted or sweet. Salted peanuts can be produced of roasted or fried kernels. After roasting or frying, peanuts are spread with oil and salt. In recent years new flavours have been developed for salted peanuts, including spicy, pepper, tomato, barbecue, onion, and basil, to name but a few examples. Processing technology of flavoured peanuts is very similar to that of salted ones. However, there are two types of flavouring sprinkles available at the market: those requiring thermal processing and those not requiring this. Hence, the use of a particular sprinkle determines whether peanuts will be roasted or fried. Peanuts coated in starch (with spices or flavours) are produced of blanched kernels, coated in starch and then fried. In Bulgaria, they are sold as 'beer peanuts' and are very popular among beer drinkers. Sweet peanuts are made of kernels (blanched or not) sprayed with the solutions of honey, caramel or sugar with water and stabilizers, and then fried. One of the peanut processors emphasized that such products are always fried: roasting is impossible due to stickiness that may damage the oven. Hence, the term 'honey roasted' is incorrect and results perhaps from a mistranslation. As in the case of flavoured peanuts, consumers have various preferences for sweet peanuts. For example, caramel peanuts have never been popular among Polish consumers; they also did not accept chicken-flavoured peanuts, which Polish manufacturers instead export on a large scale to Ukraine.

In-shell roasted peanuts as well as roasted shelled peanuts may be packed for direct consumption. Roasted whole kernels are often present in so-called 'health food products', including nuts and dried fruit mixes, breakfast cereals and musli bars. Nuts and dried fruit mixes usually consist of raisins, peanuts, other nuts (cashews, walnuts, hazelnuts) and almonds. To "premium' packs, other dried or candied fruits (i.e. cranberries, orange, pineapple) can be added. These mixes are also known as 'student food' as they are recommended as a healthy alternative to sweets during particularly intensive intellectual effort. They have started to become popular in all European countries as a healthy alternative to other snacks.
Fried and roasted peanuts are also used as intermediates for further processing. Whole roasted groundnuts are sold to confectionary producers who transform them into various peanut dragees, including chocolate or yoghurt coated, and/or glazed, or add them whole or split to chocolate and candy bars. Chopped kernels are made of blanched and roasted peanuts and are sold for cooking (baking), as additive in various chocolates, candy bars, pralines, nougats, wafers and ice-creams. They are also sold as decorative meat sprinkles after adding some food dyes. Chopped or whole peanuts are also sold to Indian, Chinese, Vietnamese, Thai or Mediterranean manufacturers and restaurants, where peanuts are an ingredient of ready meals (i.e. salads, sauces). Some oriental crackers include whole roasted kernels covered in rice and sesame film. Generally, a vast majority of products are based on blanched and roasted peanuts.

Peanut paste is made of roasted and ground peanuts, and as such constitutes a base for a broad range of products, including salted snacks and sweets. Examples of sweets containing peanut paste include wafer, chocolate confections, candy and praline filling, some dragees, halva, as well as a number of chocolate creams (spreads, i.e. cashew butter). To produce sweet filling, peanut paste is homogenized with milk, sugar and stabilizers (sometimes finely chopped peanuts are added to the filling). Peanut paste salted and seasoned may be used in a number of salted snacks, such as corn crisps. In Bulgaria, a special peanut paste called tahina is produced of skinless roasted peanuts. It is very similar to peanut paste, and likewise peanut paste constitutes a base for many products, including salad dressings, desserts, spreads, snack dips, and halva. Yet, tahina can be also consumed directly in the form of spread or bars. Bulgarian manufacturers use peanut paste to produce peanut dressings (paste homogenized with water, egg mix, spices and refined sunflower oil). Peanut paste is also used to produce peanut butter, which in turn can be a component of other products, such as peanut punch or candy bars. Nowadays, many peanut butter producers buy peanut paste from the processors and mix it with taste improving agents. Interestingly, peanut butter is not very popular in Europe, while in the USA a majority of peanut supply is processed for butter. 
Peanut flour is made of partially defatted and finally ground roasted peanuts, in dry powder form. It is a an ingredient of various confectionary and bakery products, energy snacks and drinks (i.e. energy bars) as well as sauces, dressings and giblets. It has some technical advantages in food production, such as increasing shelf life through reducing the amount of fat, and eliminating the migration of peanut oil to cocoa butter in chocolate confections. However, most processors and manufacturers interviewed did not use peanut flour.

Finally, shells, skins and kernels are used to make a broad variety of non-food products. For example, the shells may be used in wallboard, fireplace logs, fibre roughage for livestock feed and kitty litter. Peanuts are often used as an ingredient in other products such as detergent, salves, metal polish, bleach, ink, axle grease, shaving cream, face creams, soap, linoleum, rubber, cosmetics, paint, explosives, shampoo, and medicine. In African and Asian countries, peanut plants are used in agriculture (hay and animal feed). Peanut meal/peanut cake (made from the by-product of peanuts pressed for oil) is an important high protein animal feed. In the UK, a lot of peanut supply is used in the bird market. One trader also said that most peanuts are for industrial, not food use.

\section{DISCUSSION}

The schema demonstrates a range of end products that are based on peanuts and the processes they undergo from the beginning of the chain (i.e. shelling). Products based on roasted peanuts appear the most allergenic. However, the majority of foods are based on roasted peanuts, including salted, sweet and flavoured peanuts, peanut butter, chocolates, confectionary, wafers, ice-creams, and ethnic food (i.e. Indian or Thai cuisine) using chopped roasted kernels in salads and meat. However, some processors admitted that for the consumers, it is difficult to distinguish between roasted and fried peanuts.

It is worth noting that the peanut processing schema involves various actors, who may play multiple roles in the chain determined largely by the costs. Traders import peanuts in various forms - in-shell, shelled, peanut oil, raw or blanched. Some traders also process peanuts, i.e. Bulgarian traders fry, roast, and produce salted or flavoured peanuts, peanut butter, flour and peanut oil. Traders sell peanuts to processors (i.e. roasters), confectionary traders, food manufacturers, bakers, retailers, health food shops and supermarkets. Bulgarian traders pointed out that there are high taxes in large supermarkets so they trade only with smaller ones. Peanut processors purchase groundnuts from traders or directly from producers or dealers in the country of origin. For instance, British manufacturers purchase peanuts from traders or directly from a co-operative in the production area. In Spain, processors import raw peanuts but in different forms: in shell, shelled and shelled without skin. They process peanuts and sell them to traders, food manufacturers (especially confectionary producers and bakers) and to large supermarkets. Confectionary producers buy peanuts mostly in roasted form or in form of the peanut paste. They purchase peanuts either from a national processor or from the country of origin. Some respondents pointed out that it is cheaper to blanch peanuts in a country of origin. In Poland, food manufacturers buy already processed peanuts from national peanut processors. In the past, they processed peanuts themselves (mostly by roasting), but now it is cheaper to buy from external suppliers. The only processing they do is grinding peanuts with sugar and milk to produce wafer filling. Finally, all goods are sold to supermarkets, who in all countries are the main distributors of peanuts, although peanuts are also sold in small shops or at green markets.

Peanut processing technology has not been subjected to major changes over the years. All processors pointed to new machinery that allows a higher capacity of processing, but technology per se has not been altered. Yet, the peanut processing machinery lasts for a very long time and therefore many processors and manufacturers (especially smaller ones) may have equipment older than thirty years. Manufacturers would not invest in new equipment or technology if the peanut market were unstable, as it is in Bulgaria. Besides, different oils are also used to fry peanuts now comparing to some years ago, i.e. sesame oil (Bulgaria) or palm oil (Poland) instead of more expensive peanut oil. A Polish manufacturer asserted that he last used peanut oil for frying 12 years ago. Other differences between the current and previous peanut processing practices, brought up by the new EU member 
states (Bulgaria, Poland), related to strict safety procedures imposed by EU norms. Some manufacturers also noted that in the past, they processed peanuts by themselves, while now it is cheaper to buy them already processed from external supplier, mostly national peanut processor. Nonetheless, a UK informant stated that it is cheaper to buy peanuts processed in the country of origin, rather than from a domestic processor.

\section{CONCLUSIONS}

This paper has analysed the various stages of the peanut food chain, starting with cultivation and then moving on to the processing methods. The nature of peanut cultivars, and the source of the main importers of peanuts into Europe have been also discussed. The aim of the analysis was to provide a baseline understanding of the sources of variability in peanut products that might potentially inform our understanding of differences in peanut allegy across countries (which has been verified, although the precise differences across the countries in this study, and Europe more widely, has yet to be documented, although it is a goal of the EU-funded project of which this research was a part). Our analysis was intended to be based on a documentary review of evidence, although our searches revealed that much of the evidence we sought simply did not exist or was not practically attainable. As such, we needed to fill out the peanut 'schema' through accessing key experts, conducting interviews with an array of relevant experts, such as peanut farmers, processors, traders and food manufacturers. The study was carried out in four European countries having different experiences with peanuts, namely Spain, Bulgaria, UK and Poland. The analysis of peanut import to Europe indicated that the EU countries import peanuts mainly from Argentina, China and the US. However, neither country of origin nor peanut cultivars seem to have impact on peanut allergenicity. The main factor responsible for the increased allergenicity of peanuts thus far determined by research - is the application of high temperatures $\left(280^{\circ} \mathrm{C}\right)$, which is typically applied during roasting. Frying and boiling are also thermal processes, but fried and boiled peanuts are known to be associated with lesser allergenicity.

Further research is necessary concerning this issue, as it has been observed that societies in which peanuts are consumed in fried or boiled forms (i.e. China) have lower peanut allergy prevalence compared with the societies consuming roasted peanuts (i.e. US). However, according to our schema, a majority of peanut products at the European market are based on roasted kernels, which is important information for consumers with peanut allergy. More research is also needed as regards the influence of various additives, such as chocolate (which is also considered an allergen) on the allergenicity of peanuts. In addition, the use of peanuts in non-food products needs more investigation. Peanut oil is used in many popular cosmetics and in vitamins. Shells, skins and kernels are also present in cosmetics, medicines and household chemicals. However, most of the key informants interviews during this study in four EU countries had no or very little information on peanut allergenicity. The main health safety concern mentioned by almost all the respondents was not allergy but aflatoxins, discussed extensively with respect to the country of origin.

\section{ACKNOWLEDGMENTS}

This research was supported by the EU through the EuroPrevall project (FOOD-CT-2005-514000). The authors are grateful to the partners from the project V. Gancheva and Y. Strek from Association APPEL EUROPA, Sofia Bulgaria, B. Sora and R. Sala from Centro de Investigaciones Energeticas, Medioambientales y Technologicas, Madrid, Spain and J. Houghton, University of East Anglia, UK.

\section{REFERENCES}

Beyer K., Morrow E., Li X.M., Bardina L., Bannon G.A., Burks A.W., Sampson H.A., 2001. Effects of cooking methods on peanut allergenicity. J. Allergy Clin. Immun. 107 (6), 1077-1081, doi: 10.1067/mai.2001.115480.

Bock S.A., Muñoz-Furlong A., Sampson H.A., 2007. Further fatalities caused by anaphylactic reactions to food, 2001-2006. J. Allergy Clin. Immun. 119 (4), 1016-1018, doi: 10.1016/j.jaci.2006.12.622.

Boulay A., Houghton J., Gancheva V., Sterk Y., Strada A., Schlegel-Zawadzka M., Sora B., Sala R., van Ree R., Rowe G., 2008. A EuroPrevall review of factors affecting incidence of peanut allergy: priorities for research and policy. Allergy 63 (7), 797-809, doi: 10.1111/j.1398-9995.2008.01776.x. 
Craig W.J., Mangels A.R., 2009. Position of the American Dietetic Association: Vegetarian diets. J. Am. Diet. Assoc. 109 (7), 1266-1282, doi: 10.1016/j.jada.2009.05.027.

Directive 2003/89/EC of the European Parliament and of the Council of 10 November 2003 amending Directive 2000/13/EC as regards indication of the ingredients present in foodstuffs. 2003. Off. J. EU L, 308, 15-18.

EUROSTAT statistics (n.d.). 2014. [online], http://epp.eurostat.ec.europa.eu/portal/page/portal/international_trade/ data/database [retrieved: March 15, 2014].

FAOSTAT (n.d.). 2014. [online], http://faostat.fao.org/site/ 609/default.aspx\#ancor [retrieved: March 15, 2014].

Fernández-Rivas M., Asero R., 2014. Which foods cause food allergy and how if food allergy treated? In: Risk Management for Food Allergy. Elsevier 25-43, doi: 10. 1016/B978-0-12-381988-8.00002-6.

Khalil J.K., Chughtai M.I.D., 1983. Chemical composition and nutritional quality of five peanut cultivars grown in Pakistan. Qual. Plant. 33 (1), 63-70, doi: 10.1007/ BF01093738.

Kita A., Figiel A., 2007. Effect of parameters of thermal process on the properties of peanuts. Pol. J. Food Nutr. Sci. 57 (4B), 285-290.

Maleki S.J., Chung S.Y., Champagne E.T., Raufman J.P., 2000. The effects of roasting on the allergenic properties of peanut proteins. J. Allergy Clin. Immun. 106 (4), 763-768, doi: 10.1067/mai.2000.109620.

Maleki S.J., Viquez O., Jacks T., Dodo H., Champagne E.T., 2003. Can processing be used to reduce allergenic properties of peanuts? J. Allergy Clin. Immun. 111 (2), S195, doi: 10.1016/S0091-6749(03)80668-1.

Matsunaga A., 1974. Method of making peanut flour (US patent 3829589). United States: United States Patent.

Mondoulet L., Paty E., Drumare M.F., Ah-Leung S., Scheinmann P., Willemot R.M., Wal J.M., Bernard H., 2005. Influence of thermal processing on the allergenicity of peanut proteins. J. Agr. Food Chem. 53 (11), 4547-4553, doi: 10.1021/jf050091p.

Emission factor documentation for AP-42. Section 9.10.2. Salted and roasted nuts and seeds. Final report. 1994. U.S. Environ. Prot. Agency Office Air Qual. Plan. Stand. Emmis. Invet. Branch, 1-28.

Vickery B.P., Chin S., Burks A.W., 2011. Pathophysiology of food allergy. Pediatr. Clin. North Am. 58 (2), 363-376, doi: 10.1016/j.pcl.2011.02.012.

Zhou Y., Wang J., Yang X., Lin D., Gao Y., Su Y., Yang S., Zhang Y., Zheng J., 2013. Peanut allergy, allergen composition, and methods of reducing allergenicity: A review. Int. J. Food Sci. Technol. 1-8, doi: 10.1155/2013/ 909140.

\section{CHARAKTERYSTYKA ŁAŃCUCHA ŻYWNOŚCIOWEGO ORZESZKÓW ZIEMNYCH W EUROPIE - POWIĄZANIE Z WYSTĘPOWANIEM ALERGII NA ORZESZKI ZIEMNE}

\section{STRESZCZENIE}

Wprowadzenie i cel badań. Orzeszki ziemne są uważane za jeden z głównych alergenów, odpowiadający za silne reakcje alergiczne. Dlatego można znaleźć wiele badań, których celem jest identyfikacja powiązań pomiędzy występowaniem alergii na orzeszki ziemne a metodami ich przetwarzania w łańcuchu żywnościowym. Celem artykułu jest opisanie doświadczeń europejskich związanych z uprawą orzeszków, ich handlem zagranicznym oraz sposobami przetwarzania, na przykładzie czterech krajów mających różne w tym zakresie doświadczenia (Polska, Bułgaria, Hiszpania, Wielka Brytania).

Materiał i metody. Wyniki badań są oparte na analizie dokumentów oraz wywiadach półstrukturalnych i bezpośrednich z 32 ekspertami zaangażowanymi w różne etapy łańcucha żywnościowego orzeszków ziemnych, w tym rolnikami, przetwórcami, handlowcami, technologami żywności i producentami.

Wyniki. Schemat łańcucha żywnościowego orzeszków ziemnych został sporządzony z uwzględnieniem orzeszków ziemnych w łupinach i skorupce. Analizę każdego etapu przetwarzania orzeszków przeprowadzono zgodnie z tym schematem. Procesy termiczne i mechaniczne omawiano równolegle dla uzyskanych produktów końcowych, dostępnych dla konsumentów europejskich. W dokumencie przeanalizowano także główne tendencje w handlu orzeszków ziemnych w Europie. Wyniki wskazują, że na większość produktów składają się orzeszki ziemne w postaci prażonej, uważane za najbardziej alergizujące, co powoduje zwiększoną ekspozycję ludności.

Wnioski. W przedstawionym schemacie i w dyskusji uwzględniono różne aspekty produkcji, handlu i przetwórstwa orzeszków ziemnych. Głównym czynnikiem związanym ze zwiększoną alergennością orzeszków 
Prusak A.M., Schlegel-Zawadzka M., Boulay A., Rowe G., 2014. Characteristics of the peanut chain in Europe - implications for peanut allergy. Acta Sci. Pol., Technol. Aliment. 13(3), 321-333.

wydaje się wysoka temperatura prażenia. Smażenie i gotowanie również są procesami termicznymi, ale orzeszki ziemne smażone i gotowane są łączone ze zmniejszeniem objawów alergenności. Kraj pochodzenia i rodzaj odmiany wydają się nie wpływać na zmniejszenie alergenności orzeszków. Istnieje potrzeba większej liczby badań, by ocenić wpływ różnych dodatków na uczulające właściwości produktów z orzeszków ziemnych (np. czekolada uważana również za alergen). Dalszych badań wymaga również stosowanie orzeszków w produktach nieżywnościowych.

Słowa kluczowe: alergia na orzeszki ziemne, łańcuch żywnościowy, przetwórstwo orzeszków ziemnych, gatunki orzeszków ziemnych

Received - Przyjęto: 12.03 .2014

Accepted for print - Zaakceptowano do druku: 16.05.2014

For citation - Do cytowania

Prusak A.M., Schlegel-Zawadzka M., Boulay A., Rowe G., 2014. Characteristics of the peanut chain in Europe - implications for peanut allergy. Acta Sci. Pol., Technol. Aliment. 13(3), 321-333. 